\title{
A Sociological Review of Peepli Live 2010
}

Dr Shivam ${ }^{+}$

\begin{abstract}
Marginalisation is a process of distancing (either by coercion or voluntarily) from the centre and relegate to the margin. In the social context, this marginalisation is lack of importance to certain socially disadvantaged groups. This disadvantage might be due to caste, class, gender or lack of political opportunities. However, within the same society there are privileged groups who are at the centre of all importance. This difference between advantaged groups at the centre and disadvantaged (marginalised) groups at the periphery has been problematised in popular media like cinema. The present paper shows that how marginalised sections are portrayed in Hindi cinema? For this, the cases of Peepli Live released in 2010 have been selected. The paper has been divided into two parts. The first part deals with the farmer's suicide and the second part with the politics of suicide and the politics of marginalisation. These issues have been taken keeping in mind the recent problems of the marginalised sections in society, especially the problems faced by the farmers in contemporary times. Various studies and news reports show that farmers' suicides are post 1990s phenomena inflated by the undertaking of measures to open Indian economy by the methods of liberalisation, privatisation and globalisation (LPG). This was the phase, which witnessed incredible growth of the industrial sector as compared to the agricultural sector. These facts were enough to break the myth of 'developing' India. In fact, the increasing number of farmers' suicide rather depicted government's bias towards economic growth neglecting socioeconomic concerns of the farmers. At this juncture of bias and neglect, one can identify a breeding ground for politics of suicide from farmers' side and politics of marginalisation from the politicians' side. Sociologically, however, a multiple socio-economic factors are theorised to be responsible.
\end{abstract}

Key words: Marginalisation, farmers' suicide, agriculture, caste, politics, India

\footnotetext{
${ }^{+}$Dr. Shivam, Assistant Professor, Department of Sociology, University of Rajasthan, JLN Marg, Jaipur 302004 Email: drshivamjnu@gmail.com

(C)2015 Shivam. This is an Open Access article distributed under the terms of the Creative Commons Attribution License (http://creativecommons.org/licenses/by/2.0), which permits unrestricted use, distribution, and reproduction in any medium, provided the original work is properly cited.
} 


\section{Introduction} issues witnessed in contemporary Indian society. Circumventing on the issue of farmers' suicide, this film took under its fold the connecting issues like caste politics, centrestate relations and intervention of posh, urban Indian media to rural India. There are also instances of gross sensitisation of the issues by the media for acquiring extreme viewership. However, this aspect shall not be discussed, as it is primarily not concerned with the main theme of the paper.

\section{Topic of discussion can be categorised as}

- Farmers' suicide in developing India; and

- Politics of suicide and politics of marginalisation

At the outset, I would like to focus on my curiosity regarding the reality of 'developing' India. This reality can be more questioned especially after the 1990s. This was the period when the wave of liberalisation, privatisation and globalisation (LPG) was felt in India. These questions are:

- Was it a period of development or retardation?

- Is the concept of developing India a myth?

- What must be the criteria for development?

These observations are:

- Rise in Gross Domestic Product (GDP) or rise in number of multinational companies?

- Or, is rise in violence, consumer culture or farmers' suicide?

Kumar (2011) cites the report prepared in April 2004 by the United States-based financial services leader Goldman Sachs that looks on the extreme paradoxes existing in India. That claiming on the contradiction that exists in the country it says that India contains as high as one-third of the world's software engineers.
Peepli Live 2010 is a satire on various serious

Side by side, it also contains one fourth of the world's undernourished (Kumar, 2011: 175). Therefore, it is quite clear that the propaganda of developing India is not universal. Mainly the middle and the rich classes enjoy the fruits of development and very less becomes available for the poor classes. Kumar (2011) explains it with the concept of Americanisation of the middle class and Africanisation of the masses. He writes:

There are certain myths and realities about Indian engagement with globalisation. However, globalisation is here to continue despite its contradictions. Moreover, so far globalisation has promoted Americanisation of the middle classes and Africanisation of the masses. Here, Americanisation is to be understood as moving towards affluence and consumerism through liberalisation and privatisation, and Africanisation is to mean growing unemployment, poverty, malnutrition, social violence, corruption, exploitation by multinational companies and crises of governance. (Kumar, 2011:176)

Therefore, the concept of development has differential meaning for different sections of the society. On the one hand, we see rise in industrial and technological sector. On the other hand, there is severe crisis in agriculture sector due to negative growth rate. Consequently, there are alarming rise in farmers' suicide and rural unrest.

\section{Farmers' Suicide in Developing India}

Before going into details of sociological explanations of farmers' suicide, it is important to know the difference between farmers and peasants. The concept of farming is more close to capitalist agriculture, although farmer and peasant can be used interchangeably in popular usage. ${ }^{1}$ In India, farmers are peasants; land has

\footnotetext{
1 Martín Koppel (2003). Difference between Peasants, Farmers? , The Militant, March 24, Vol. 67/No. 9

Available at
}

(C)2015 Shivam. This is an Open Access article distributed under the terms of the Creative Commons Attribution License (http://creativecommons.org/licenses/by/2.0), which permits unrestricted use, distribution, and reproduction in any medium, provided the original work is properly cited. 
special significance for peasants. It is not only a source of occupation but it is a culture too. Precisely, it is something with which they are attached to both culturally and emotionally. Economically, they consider it as their hereditary property. Therefore, they are always keen to transfer it to the next generation. Emotionally, they revere their cultivating land equivalent to their mother. Indian peasants always want to keep their mother in one hand. At the same time, farming is quite professional occupation without much cultural significance. Word Dharti Maata (mother earth) has been used in Indian film Upkar (1967) when Puran demands to divide the land; Bharat replies, "the land is our mother. We don't divide our mother" (Virdi, 2003: 38).

There are two important questions that must be answered. First, what are socio-economic factors, which cause farmers' suicide? Second, why is it rising in contemporary times? There might not be one single explanation for farmers' suicide. It needs to be dealt with a bunch of permutation and combination for explanation. Durkheim's theory of suicide can be linked to the contemporary farmer's suicide. When social regulations break down, the controlling influence of society on individual propensities are no longer effective and individuals are left to their own devices. Such a state of affairs is referred to by Durkheim as anomie, a term that refers to a condition of relative normlessness in a whole society or in some of its component groups. Durkheim (1951: 254) argued that wealth, by stimulating human desires, carries with it dangers of anomic conditions because it does not impose "restraint upon aspirations", and "deceives us into believing that we depend on ourselves only," while "poverty protects against suicide because it is a restraint in itself...." Since the realisation of human desires depends upon the resources at hand, the poor are restrained, and hence, are less prone to suffer from anomie by virtue of the fact that they possess but limited resources. "The less one has the less he is

http://www.themilitant.com/2003/6709/670936.html (accessed on 11 February 2015) tempted to extend the range of his needs indefinitely" (Durkheim, 1951: 254).

Therefore, from the above discussion, it can be clear that poverty among farmers existed even during the 1950s. But there was satisfaction with subsistence farming for livelihood. Hence, one can derive that farmers during the 1950s were less ambitious and so did not think of committing suicide (see Do Bigha Zamin [1953] where farming is in the form of subsistence farming and hardly had any incidence of farmer's suicide). However, in the post 1990s, there is more emphasis on capitalist farming as a source of livelihood. As a result, there is more emphasis on cash crops, contract farming, etc. This has led to more desire for economic benefit. In case they fail, it turns into anomie and finally, anomic suicide (Nagaraj, 2008:1, Jodhka, 2005:20, please see below for detailed discussion. Durkheim argues that the incidence of suicide varies widely across societies and historical periods. The psychological dislocation that causes suicide has deep social roots. Various causes increase the rate of suicide in industrial society, such as the dislocation of social bonds as individuals move away from their family and community life. The infinite extension of market arouses the greed, unable to find ultimate foothold (see Durkheim, 1951). Quoting Durkheim's work, Lukes (1973: 195) points that in modern towns driven by commerce and enterprise, men lose the less close', as 'the cold winds of egoism freezes their hearts and weakens their spirits'. Consequently, 'the bond attaching man to life slackens because the bond which attaches him to society is itself slack' (1973: 206).

Thus, analysing from the theoretical lens of Durkheim it can be said that it is greed, more desire in capitalist farming and dislocation of various social bonds like family and community causing farmers' suicide. However, this is all about theory. Now let us have a look on what the other researches and observations has to say on this crucial issue? Different studies has different explanations such as the impact of neo-liberal economic policies including the integration of Indian agriculture into the world 
market (Shiva and Jafri, 1998; Patnaik, 2004, 2006); increasing costs of production (Vyas, 2004, Mohanty and Shroff, 2004); inadequate institutional support including lack of availability of credit; deceleration in rural growth (Dev, 2004, Rao and Gopalappa, 2004, Ghosh, 2004); decline in wages, growing indebtedness and unemployment (Patnaik, 2004; Dev, 2004; Sarma, 2004), frequent loss of production, and as the results of a triple crisis of economy, society, and ecology (Vasavi, 1999), etc.

Reference can be made to a scene in the film Peepli Live 2010, where the farmers contemplate on the commercialisation and mechanisation of agriculture. As a result, they have become more dependent on American seeds and fertilisers, distancing them from traditional, indigenous agricultural knowledge. The next section however outlines the methodologies deployed.

\section{Methodology}

The methodology used for the study is narrative analysis (both audio and visual) where narratives, scenes are explained in terms of sociological theories and sociological observation. The context of time and space has been taken into consideration. Internet has been used. Italics have been used for Hindi words, the name of the cinema, cinematic character and narratives of the cinema.

\section{Narrative: 1 (from Peepli Live 2010)}

Farmer: What is in the farming? Put American seeds, American fertilizers, and expect rain from god!

The above statement can be linked with Vasavi's writings:

In the context of increasing commercialization of agriculture, the intensity of competition among agri-business players and the growing distance of State extension service personnel have meant that agricultural practices are increasingly dictated by market-led fads. The result is intense competition among agriculturists to out compete each other by using new commercial varieties of seeds, fertilizers, and pesticides. Such absorption and adaptation of fads, while displacing their own local knowledge systems, has also led to increasing 'agricultural deskilling' (Stone, 2007) that is the inability to use appropriate and relevant knowledge and practices. ${ }^{2}$

The intervention of market, new technology, and hybrid seeds into agriculture made agriculture as individualised profession; but it is a traditional occupation embedded in caste system. Therefore, the individual actor (the farmer) survives in the two lived worlds. In one lived world the farmer gives priority to economic advancement. However, if this priority fails, then there are serious repercussions causing shame, dishonour, and sometimes-resulting suicide. Further, Vasavi argues that the more the farmers are integrated into the market economy and subscription to agriculture changes the cultural basis of Indian agriculture. It has also affected the rolling back of state, the breaking of patronclient relations, and the decline of traditional and customary structure. As a result, there is excessive dependence on external structures and agencies. "While the disintegration of the customary forms of support has also liberated the working, low-ranked caste groups and enabled them to escape from caste prescribed subservience and debt servicing, the provisioning mechanisms of the moral economy have not been adequately replaced by State mechanisms of provisioning (Aurora, 2004; Vasavi, 1999). Vasavi also writes:

For those economically and socially marginal in the system, the games of the new agricultural modernity induce and indict them into new risks. However, the individualized economic actor remains embedded within the social and cultural fabric of his or her society and is therefore circumscribed by its norms and values of honour, shame, and responsibility. What results is the working of two differing sets

\footnotetext{
${ }^{2}$ Vasavi, A.R. Suicides and the Making of India's Agrarian Distress, National Institute of Advanced Studies IISc Campus Bangalore, available at: http://www.yale.edu/agrarianstudies/colloqpapers/04va savi.pdf, p.5 (accessed on 28 January, 2015)
} 
of cultural logics; that of the new economic regime that privileges the individual acting for his or her own economic benefit and the pressures of the social world that enforces them to subscribe to its dictums and priorities. ${ }^{3}$

The film Peepli Live 2010 shows failure of various governmental schemes generally planned for welfare. Here, we can take the example of provision of loans for the farmers. The logic of providing loans to the farmers is to save them from the clutches of traditional loan providers (Mahajans). This was a progressive idea to boost agriculture. However, such foresight did not work as per expectation. It has rather created far more adverse situation. Now the bank seems more exploitative as it started grabbing farmers' agricultural land on the latter's failure to repay the loan .This has left the poor farmers only with no other possibility, but suicide as it is shown in Peepli Live 2010.

The film Peepli Live too shows that how Natha and Budhia confront in two lived worlds. They, on the one side, face stress and humiliation by banking institution who auctioned their land. Simultaneously, on the other side they bear the disgrace and disregard created by the family members (Dhaniya and his mother).

Therefore, the factors responsible for farmers' suicide are not uniform - it is embedded with multiple social, cultural and political factors. Two other things must be discussed here. First, is the institutional bank loaning enough and hassle free to fulfil the agricultural requirement of the farmers and second, how do farmers use these institutional loans? No proper use of institutional bank loans by farmers too creates a heavy pressure on farmers and especially on marginal farmers. In the said context, Jodhka (2005) writes:

The available institutional credit was simply not enough. The Arhtias fulfilled the gap in availability of credit from institutional sources and the total demand for credit in rural Punjab

\footnotetext{
${ }^{3}$ Vasavi, A.R. Suicides and the Making of India's Agrarian Distress, National Institute of Advanced Studies IISc Campus Bangalore, available at http://www.yale.edu/agrarianstudies/colloqpapers/04va savi.pdf, p.10 (accessed on 28 January, 2015)
}

(Gill, 2004). Arhtia's credit also involved lesser paper work and other bureaucratic hassles. ${ }^{4}$ Further in reply of second question Singh et al. (2005) focus on the purpose of borrowing money. Money was borrowed for both "productive" (41 percent) and "unproductive" (59 percent) purposes. Though all categories of farmers borrowed heavily for "social" needs, the share of "unproductive" borrowings was highest amongst marginal farmers (71 percent) and comparatively lesser amongst large farmers (48 percent). Nearly half of the money borrowed for "unproductive" purposes was spent on marriages and other social functions. ${ }^{5}$

The last two decades observed a large number of farmers committing suicides in different parts of India. These suicides, which reached almost epidemic proportions in certain pockets of the country, were first picked up and reported by an alert press around the late 1990s (see Nagaraj, 2008). Therefore, the epidemic rise in farmer's suicide is post-1990s phenomena which is caused by "the crisis of ecology" and "disintegration of community" caused by the new technology, and accentuated by globalization" (Jodhka, 2005:20).

A negative trend was observed during the onset of Green Revolution that started in the 1960s. Indeed, it has changed the agricultural pattern (traditional crop to cash crop). It has also increased heavy burden on exterior inputs such as fertilizers, machines and technology. Green Revolution not only meant for technological innovations, prosperity to farmers, surplus production but also came with negative

\footnotetext{
${ }^{4}$ Surinder S. Jodhka. (2005). Beyond "Crises": Rethinking Contemporary Punjab Agriculture: GAPS Series, p 15, (Working Paper: 4, May 2005), available at: http://www.cess.ac.in/cesshome/wp\%5CGAPs_WP4.pdf, (accessed on 28 January 2015).

${ }^{5}$ Surinder S. Jodhka. (2005). Beyond "Crises": Rethinking Contemporary Punjab Agriculture: GAPS Series, p 16, (Working Paper: 4, May 2005), available at: http://www.cess.ac.in/cesshome/wp\%5CGAPs_WP4.pdf, (accessed on 28 January 2015).
} 
consequences $^{6}$. Shiva too shows the negative consequences:

Atomized and fragmented cultivators related directly to the state and the market. This generated on the one hand, an erosion of cultural norms and practices and on the other hand, it sowed the seeds of violence and conflict (Shiva 1991: 171).

Utsa Patnaik draws an analogy between the crises of the farmers during the colonial era to that of the contemporary era. In the British era, farmers were compelled to produce commercial crops like cotton. It was only because British needed it for their textile mills. In the similar manner, in the current scenario, farmers are being 'used' by $\mathrm{MNCs}^{7}$ for the latter's need of commercial crops.

Utsa Patnaik (2004) writes:

...lakhs of small farmers were switching from food crops to cotton as the world prices were rising. Many of them had not cultivated cotton before.... There was this sudden expansion of area under cotton - these farmers could not afford to do so except on the basis of credit. They took loans and the amount of loans they took to produce cotton was much higher than they had taken in the past, as they would have grown rain-fed food crops on the same land, which would not have cost much for production. $^{8}$

Therefore, switching over from food crops to commercial crops causes increasing indebtedness, which further led to depression, dishonour and finally committing suicide. Although, the film has raised the crucial issue of

\footnotetext{
${ }^{6}$ Vasavi, A.R. Suicides and the Making of India's Agrarian Distress, National Institute of Advanced Studies IISC Campus, Bangalore-560012 p.5, available at:

http://www.yale.edu/agrarianstudies/colloqpapers/04va savi.pdf,(accessed on 28 January 2015) date/year has not been on the original source.

${ }^{7} \mathrm{~A}$ multinational corporation or multinational enterprise is an organisation that owned or controls productions of goods or services in one or more countries other than the home country.

${ }^{8}$ Patnaik, Utsa (2004) 'It is a crisis rooted in economic reforms' Frontline (net edition) Volume 21 (13), June. 19 July.02.http://www.frontline.in/navigation/?type=static\& page=archive (accessed on 28 January 2015).
}

farmers' suicide yet it also brings under its fold the colours of politics. Finally, there is emphasis on preventive measures that can be utilised to prevent farmers' suicide. As it was shown in the movie that one of the major causes of farmers' suicide is debt burden. To prevent this, some steps can be taken like: (1) supplementary occupation must be promoted among the farmers, (2) there is a need to invest more on dry land development and enhance the sustainable irrigation, (3) effective farm credit policy, (4) from a sociological perspective there is need to organise non-political, non-profit, non-governmental voluntary associations. These organisations should go to the farmers in distress, create awareness about their selfdignity, rights, modus operandi of the vested interests for profit making, etc. These should also mould a sense of self-confidence among the farmers. Further, these bodies can include agricultural experts, intellectuals, social workers, litterateurs and farmers' leaders. ${ }^{9}$

\section{Politics of Suicide and Politics of Marginalisation}

The analysis of the second part starts from the phase where caste politics become popular in Indian politics. It was a phase when so-called marginalised groups [Scheduled Castes (S.Cs), ${ }^{10}$ Other Backward Communities (O.B.Cs ${ }^{11}$ )] actively participated in Indian democracy. Their large numerical strength and equality of opportunity to participate in political process changed their socio-politico-economic status. However, unfortunately, there is no compatibility to their numerical strength and

\footnotetext{
${ }^{9}$ All four measures taken from article "A probe into socio-economic and psychological profile of farmers' suicide in Karnataka", Shrishail Nagthan, Rajendra Poddar, L.B. Kunnal, H. Basvaraja and Basavaraj Banakar, Karnataka J. Agric. Sci., 24 (2): (157-160) 2011. Available at:http://www.inflibnet.ac.in/ojs/index.php/KJAS/article/ view/783/746,(accessed on 28 January 2015).

${ }^{10}$ Scheduled Castes: The official name given in India to the lowest castes considered 'untouchable' in orthodox Hindu scriptures and practice, officially regarded as socially disadvantaged (Bhattacharyya, 2009; 2013). ${ }^{11}$ Other Backward Class (OBC) is a collective term used by the Government of India to classify castes which are educationally and socially disadvantaged (Bhattacharyya, 2009; 2013).
} 
their access to political power. Consequently, most of them are marginalised leading to politics of marginalisation, which is interrelated to caste politics. Hence, to understand the politics of marginalisation we need to begin from the caste politics in Indian society.

This film portrays the changing caste politics in contemporary India. There are three political groups who are doing caste politics over the issue of farmers' suicide (or politics of Marginalisation in two ways as Natha is a double marginalized character-first, as a farmer second, as a 'Dalit'). ${ }^{12}$

(1) A group of O.B.Cs: Ram Yadav ${ }^{13}$ is the chief minister of the state who is at the top position.

(2) A group of Generals where Thakur (Rajput) $)^{14}$

is a local leader, has intermediary position struggling for power comes after Yadav.

(3) A group of dalits where Pappu Laal has also the same intermediary position that comes after Yadav. These three groups are practising caste politics and are pursuing hardest to make it in their favour by hook or by crook. Even in contemporary times, the Chief Ministers of most of Indian states belongs to either O.B.Cs/S.Cs. For examples, the Chief Ministers of several states Bihar: Jitan Ram Manjhi, Uttar Pradesh: Akhilesh Yadav, Gujarat: Anandiben Patel, and some more. These statistics shows rise of O.B.Cs/S.Cs in politics.

A change in political attitude shows three kinds of development: (1) the change in caste politics where one sees traditional caste hierarchy (rule of upper caste) is disintegrating and emergence of new caste equation. This new equation is reflected from the rise among the Dalits and O.B.Cs, (2) Secondly, there is growing significance of village as a site for political games. F.G Bailey (1963) points out that in the late 1950 s and early 1960 s, village as a para-

\footnotetext{
12 Dalits are socio-economically disadvantaged group of India who often suffer from social segregation. The obnoxious caste system of India considers the Dalits as untouchables and the members of the lowest rung of the caste system and falls into scheduled castes (Baruah, 2014; Srivastava, 1997).

13 Yadav falls into OBCs.

${ }^{14}$ Thakur (Rajput) falls into General category.
}

political system (film Parakh (1960) shows how in the 1960s village became a place of political arena), (3) this has ensured the spread of democracy to every section of people.

Now, in this paper, focus shall be made on the politics of marginalisation. It is the politics in the name of Dalits and farmers. In fact, both state government and central government are involved in politics of marginalisation for their vote bank politics. From the film Peepli Live 2010, Natha is a rural naive person. He relies on his brother's idea about suicide so that he could secure some fortune. Natha's announcement of suicide/live suicide (suicide for money) provides ground for politicians to design politics. So the question comes here as actually who is playing politics? Is it by the politicians or by Natha's brother Bhudiya? Has Natha become a scapegoat? Observation from this critical angle is necessary because suicide has to take place with full planning. It requires full enquiry whether after suicide they will be entitled to get money or not? Or this kind of planning for suicide for money and thereby, saving of land provide sufficient ground for politics of suicide?

Further conversation between Bhudiya and Gudda Babu also suggest the same. Bhudiya asks Gudda Babu so that he can be sure about entitlements of money.

\section{Narrative: 2 (from film Peepli Live-2010)}

Bhudiya: You were saying that if I commit suicide then government would give money. From where have you heard this?

Gudda Babu: Magan's son told me, he told me when he was in rally.

Following the above conservation when Bhudiya makes sure that he will get money there is conservation between Bhudiya and Natha, which need attention.

\section{Narrative: 3 (from film Peepli Live-2010)}

Bhudiya: I have investigated that thing that if $i$ commit suicide then I will get the money.

Natha: Sure?

Bhudiya: yes sure, most probably. 
Now following the above conversation there is one more conversation that is important when both drunken Natha and Bhudhiya visit the tea stall.

\section{Narrative: 4 (from film Peepli Live 2010)}

Tea stall owner: From where are you coming? There are so many days left for election.

\section{Natha: I am going to commit suicide.}

Tea stall owner: Why are you about to die?

Bhudiya: Government gives money for suicide.

Tea stall owner: they never give anything to live people, why will they give to dead people.

Natha: If I won't die then, how I will get respect?

A local journalist, who was looking to publish some sensational news, heard the conversation between Natha and the tea stall owner and published the news in a local newspaper.

Committing suicide by farmers without any planning can be understood as a normal life's routine in India. But a planned propaganda of live suicide by Natha and Bhudhiya as it is shown in this film Peepli Live 2010 displays sheer politicisation of suicide by Natha and Bhudhiya. This politics of suicide is arguably the by-product of the apathy, rising from pathetic poor conditions of their lives and the desire to save their ancestral land. Natha's decision to commit suicide stems from their very poor living conditions and finding no way out to save their land. However, never thought of the consequences. Needless to say, politicians used this issue as a site for their vested political interests by making Natha and Bhudiya as their puppets. In short, though initially themselves Natha and Bhudiya started this game but later, ended up in a dice of shrewd game of politics.

It is really pitiable that in this entire game every other person was concerned of his or her own gain. For instance, even the local community wished Natha to die as it had helped their business to run. The politicians were striving for one's vote bank politics. Initially, Dalit leader Pappu Laal comes to Natha to heat up his Dalit politics and announces that Natha will die. Bhai
Thakur (Rajput), the caste leader comes to Natha. Fearing that political benefits are going out of his hand, he warns Bhudiya that Natha must die in two days. Then OBC Chief Minister Ram Yadav comes in person to meet Natha and makes a coalition with Dalit leader Pappu Yadav. They announce that as Natha will now get '₹100,000, so, he will not commit suicide.' At this time, Natha's body language made such pleasing expression that made the others think that this was the moment that Natha was waiting for. However, this pleasure was only short-lived. Natha's dream did not turn into reality. At the last moment, the state institution of election commission had made this announcement null and void. As the state government and local politics were relying on this live suicide issue, one would be amazed to see how the Central Government had politicised the same. It had announced a Natha Card for those farmers who are planning to suicide as a reaction to government's apathy. The heights of this politicisation can be seen when Union Minister for Agriculture declares that they can only announce of Natha Card. However, its implementation is left in the hands of the state government. So, the film is a saga of how state does politics over suicide issue.

The film Peepli Live 2010 portrays media in a negative way where it shows the nexus between media and politics - how the government controls the media and vice versa. This film also questions the accountability of the media towards the mass public. The claims that media makes that it broadcasts the truth, are not always true. In the film, the media validates the government's work by propagating it, and in return, the government supports the media by providing extra benefits. Thus, both parties are beneficiaries of the politics of marginalisation. In the film, the role of media is shown in a way that media sensitise an issue for gaining Television Rating Points (TRPs). ${ }^{15}$ The viewers might be encouraged to question the ethics of the media.

\footnotetext{
${ }^{15}$ Television Rating Point (TRP) is a tool provided to judge which programmes are viewed the most. This gives us an
} 
Rakesh, a local news reporter is shown to have assisting ITVN female reporter, Nandita Malik, during her coverage of farmers' suicide story. Rakesh, being a local reporter had a different angle for news coverage compared to Nandita Malik. When he could find the entire gamut of politics behind Natha's 'suicide', he becomes more curious. He asked Nandita Malik that why Natha's suicide is taken so seriously? Is it because there are many other farmers who are doing the same. With such curiosity, he had actually touched the main nerve of politics of suicide where there are many actors as mentioned above. The following conversation between Nandita Malik and Rakesh divulges on media's role as an actor for sensitisation helping politicisations.

\section{Narrative: 5 (from film Peepli Live-2010)}

Rakesh: Why Natha is so important for us?

Nandita Malik: Natha... Natha, you are talking about Natha! Ok! if one farmer is committing suicide, don't you think it's important?

Rakesh: Yes, it is important. But many farmers live in this village. Don't you think they are important too? There was a farmer in this village;

His name was Hori Mehtoo. His land was sold. He was surviving to dig barren land and selling it to brick factory, his earnings was approx. 1520 rupees.

\section{Nandita Malik: What is your point Rakesh?}

Rakesh: We found his dead body in a dig dug by him; people say he died of hunger. Is it not important?

Nandita Malik: Research says people are only interested in Natha. Do you know why? Because he is the original 'live suicider'. Do you have any idea how big this is?

Rakesh: If we find Natha then all problems will be solved?

Nandita Malik: No... No, we won't get any solution. Some people become doctor, some

index of the choice of the people and also the popularity of a particular channel. engineer, we are journalist, and if you can't handle this, you are into wrong profession.

Thus, the above conversation clearly indicates that media does not broadcast all the facts as news. One can hypothesise that it simply works on demand and supply theory, ${ }^{16}$ That is, it broadcast only those issues which have 'market value' and which can grab more and more eyeballs.

As there is a general believe that media is a mirror of the society so it is a general tendency among the masses to believe what it promotes. The issue of Natha's suicide is one such incident. Subsequently, it becomes more of an issue to mock at by the actors who were willing to gain from the incident. However, the country as a whole took this matter so seriously that it escalated large-scale protests demanding to save Natha. With such uproar, one can assume the power of the media in a society.

Another marginalised character shown in this movie is Natha's wife Dhaniya. She portrays the character of a rural wife who is marginalised not only being a woman but also because of lack of participation in political affairs. But she is seen to be active in domestic affairs. It is interesting to see that Natha and Bhudiya did not even consult with her before their entire 'plan' for suicide.

Conclusively, the film had taken the issue of farmer's suicide and interpreted it from various angles. It has shown the opportunist tendency of various factions like the government, the community, the media, etc. Comparing pre1990s and post-1990s Indian society, it is shown in this paper that farmers' suicide is a post 1990s phenomenon. Precisely, it is a post L.P.G phenomenon, which is characterised by emphasising pattern of agriculture from food crop to commercial crop. Nevertheless,

\footnotetext{
16 The theory that prices are determined by the interaction of supply and demand: an increase in supply will lower prices if not accompanied by increased demand, and an increase in demand will raise prices unless accompanied by increased supply. Collins Online Dictionary, available at: http://www.collinsdictionary.com/dictionary/english/law -of-supply-and-demand, accessed on (11 February 2014)
} 
governmental policies and planning focuses on economic growth neglecting the socioeconomic growth of marginalised section of Indian farmers. It is also shown in this research that how an unnoticed farmer's suicide in India (unnoticed because it is supposed to be a part of daily life's routine of Indian farmer) comes into notice when it gets media hyped political colour.

\section{References}

Aurora, G.S (2004), Core Issues in the Agrarian Economy and Society of Karnataka. In R. Baumgartner and R. Hogger (eds), In search of Sustainable Livelihood Systems: Managing Resources and Change. New Delhi: Sage publications, 247-265.

Bailey, F.G. (1963). Politics and Social Change: Orissa in 1959, University of California Press, Berkeley and Loss Angeles: Sage Publications.

Baruah, A. (2014). The Prohibition of Employment as Manual Scavengers and their Rehabilitation Act, 2013: A Review, Journal Space and Culture, India, 1(3), 9-17.

Beteille, A. (1965). Caste, Class and Power: Changing Patterns of Stratification in a Tanjore Village, University of California Press.

Bhattacharyya, R. (2009). Examining the Changing Status and Role of Middle Class Assamese Women: Lessons from the Lives of University Students, PhD thesis, Newcastle University, UK.

Bhattacharyya, R. (2013). Are We Empowered? Stories of Young Indian Working Women, Saarbrücken, Germany: Lap Lambert Academic Publishing, ISBN: 978-3-659-20580-4.

Dev, Mahendra. (2004). How to Make Rural India Shine, Economic and Political Weekly, 34 (40), 4415-4422.

Do Bigha Zamin. (1953). Directed and Produced by Bimal Roy, Distributed by Shemaroo Video Pvt. Ltd.

Durkheim, Emile. (1951). Suicide, translated by John A. Spaulding and George Simpson, The Free Press, Glencoe, Illinois.
Ghosh, Jayati. (2004). The Rural Gloom, Frontline, December 3, 105-106.

Gill, Anita (2004). Interlinked Agrarian Credit Markets: Case Study of Punjab. Economic and Political Weekly, XXXIX (33), 3741-51.

Jodhka, S. S. (2005). Beyond "Crises": Rethinking Contemporary Punjab Agriculture', GAPS Series. Working Paper: 4 May.

Koppel, Martín. (2003). Difference between peasants, farmers? The Militant, 67(9), March 24, Available at http://www.themilitant.com/2003/6709/67093 6.html (accessed on 11 February 2015).

Kumar, Anand. (2011). Understanding Globalisation and Emerging India. New Delhi: Palm Leaf Publications.

Lukes, Steven (1973). Emile Durkheim: His life and Work: A Historical and Critical Study, Stanford University Press, California.

Mohanty, B. B and Sangeetha Shroff. (2004). Farmers' Suicides in Maharashtra, Economic and Political Weekly, 32(54), 5591-5598

Nagaraj, K. (2008). Farmers' Suicides in India: Magnitudes, Trends and Spatial Patterns, Madras Institute of Development Studies, Available at: http://www.macroscan.org/anl/mar08/pdf/far mers_suicides.pdf, (accessed on 28 January, 2015).

Patnaik, Utsa (2004). It is a crisis rooted in economic reforms, Frontline (net edition) 21 (13), June. 19 - July. 02.

Patnaik, Utsa (2004). External Trade, Domestic Employment and Food Security: Recent Outcomes of Neo-Liberal Economic Reforms, MS. Paper Presented at the Conference on The Question of Asia in the New Global Order, Duke University.

Patnaik, Utsa (2006). Unleashing the Market: Global Capitalism, Deflation and Agrarian Crisis in Developing Countries. In Contested Transformations: Changing Economies and Identities in Contemporary India, eds. Mary John et al. New Delhi: Tulika Press, 53-83. 
Peepli Live. (2010) Directed by Anusha Rizvi, Produced by Aamir Khan and Kiran Rao, Distributed by UTV Motion Pictures Aamir Khan Productions.

Rao, V. M and D. V. Gopalappa. (2004). Agricultural Growth and Farmer Distress: Tentative Perspectives from Karnataka, Economic and Political Weekly, 32(54): 55915598.

Sarma, E.A.S. (2004). Is Rural Economy Breaking Down? Farmers' Suicides in Andhra Pradesh, Economic and Political Weekly, 34(28), 30873090.

Shiva, Vandana (1991). The Violence of the Green Revolution: Ecological Degradation and Political Violence in Punjab. London: Zed Books.

Shiva, Vandana (2004). The Suicide Economy of Corporate Globalization, 05 April, available at:http://www.countercurrents.org/glo-

shiva050404.htm, (accessed on 11Feburary, 2015).

Shiva and Jafri. (1998). Seeds of Suicide: The Ecological and Human Costs of Globalisation of Agriculture. New Delhi: Research Foundation for Science, Technology and Ecology.

Singh, Sukhpal, M.S. Toor and V.K. Sharma. (2005). Magnitude and Determinants of Indebtedness in Punjab Agriculture. Unpublished seminar paper, Punjab University Patiala.

Srivastava, B.N. (1997). Manual Scavenging in India: A Disgrace to the Country. New Delhi: Sulabh International Social Service International and Concept Publishing.

Stone, Glenn D (2007). Agricultural Deskilling and the Spread of Genetically Modified Cotton in Warangal, Current Anthropology, 48 (1), 67 103.

Vasavi, A. R. (1999). Agrarian Distress in Bidar: Market, State and Suicides, Economic and Political Weekly, 34 (32), pp 2263-68.

Virdi, Jyotika. (2003). The Cinematic Imagination: Indian Popular Films as Social History, Rutgers University Press, New Jersey.
Vyas, V. S. (2004). Agrarian Distress: Strategies to Protect Vulnerable Sections, Economic and Political Weekly, 32(54), 5591-5598.

\section{Acknowledgement}

Foremost, I would like to express my sincere gratitude to Executive Editor, Dr. Rituparna Bhattacharyya who has given me continuous support for the publication and proper guidance with her immense knowledge. Her guidance helped me to write a good paper.

I would also like to thank to anonymous reviewers who reviewed my paper with sincerity and honesty as being value neutral, which helped me to revise my paper and making it up to date.

My sincere thanks also go to the Editorial Board of the journal "Space and Culture", India.

I thank my fellow colleagues of Department of Sociology; Rajasthan University and Head of the Department Prof. S.L Sharma; who all gave me pleased and peaceful environment to write and revise this paper.

Last but not the least; I would like to thank my family: my parents, my friend Priyanka Chakrabarty who has not only edited the paper but also introduced the Journal Space and Culture, India. 